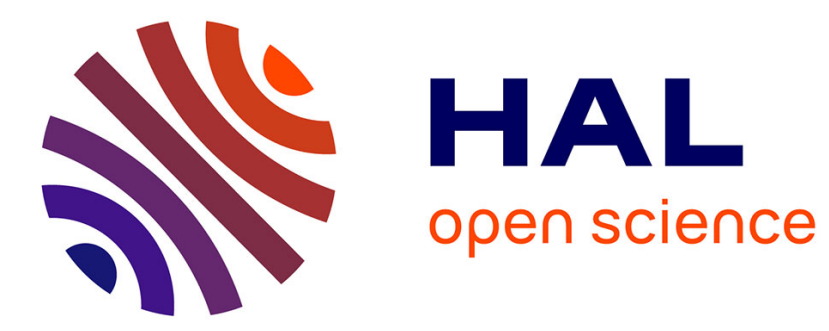

\title{
Papyrus, Greco-Roman period
}

Jean-Luc Fournet

\section{To cite this version:}

Jean-Luc Fournet. Papyrus, Greco-Roman period. Roger S. Bagnall; Kai Brodersen; Craige Brian Champion; Andrew Erskine; Sabine R. Huebner. Encyclopedia of Ancient History, IX, pp.5057-5058, 2013, 10.1002/9781444338386.wbeah12168 . hal-01597505

\section{HAL Id: hal-01597505 \\ https://hal.science/hal-01597505}

Submitted on 28 Sep 2017

HAL is a multi-disciplinary open access archive for the deposit and dissemination of scientific research documents, whether they are published or not. The documents may come from teaching and research institutions in France or abroad, or from public or private research centers.
L'archive ouverte pluridisciplinaire HAL, est destinée au dépôt et à la diffusion de documents scientifiques de niveau recherche, publiés ou non, émanant des établissements d'enseignement et de recherche français ou étrangers, des laboratoires publics ou privés. 


\section{Papyrus, Greco-Roman period}

JEAN-LUC FOURNET

Papyrus, invented by the ancient Egyptians, quickly became the main writing material used in the Mediterranean world and was employed until ca. $1100 \mathrm{CE}$, when it ceased to be used in Constantinople. The Greeks adopted it at least from the sixth century BCE onwards. Owing to its dry climate, Egypt is the only country to preserve in any quantity the texts written on papyrus during the Greek, Roman, and Byzantine periods. The bureaucracy developed by the Ptolemaic administration may have intensified, there more than elsewhere, the use of papyrus - and later the Roman administration took advantage of this situation.

Papyrus was not the only writing material: ostraca (potsherds), wooden or wax tablets, and, later, parchment and paper, were also used, which eventually ousted papyrus, even taking its name. But making up nearly seventy percent of the papyrological documentation, papyrus is by far the most widespread medium, used for documents as well as for literary texts.

Papyrus (Greek chartês, hence Latin charta, English chart) was manufactured in the form of rolls. A roll (Greek biblos, chartês, or tomos, Latin volumen) was made up of sheets (kollêma, pl. kollêmata) pasted together and was several meters in length (a standard roll composed of thirty sheets was $3.40 \mathrm{~m}$ long) and an average of $30 \mathrm{~cm}$ high. The inner face the only one usually written on (except when the roll was reused) - presented a surface where the fibers were horizontal, contrary to the outer face. The first sheet of the roll (with a reverse fiber orientation), perhaps added subsequently, was regarded as protecting the roll. From the fifth century onwards, before marketing, a stamp was applied (called prôtokollon), the legal value of which is still debated.

Used for copying literary works or for recording deeds or accounts, the book-roll was written in columns (Greek selides, Latin paginae). It could be fitted with a label with the name of the author and the title of the work (sillybos).

At the beginning of the Roman Empire, the codex came from Rome and in the course of time supplanted the roll as a book-form (see CODEX).

In most cases, the text to be written was shorter than the roll length, so the required sheet was cut from the roll. The sheet could be employed in two ways: with the writing along the fibers or across the fibers (the latter mode is called transversa charta, i.e., "the roll having been turned transversally"). It could be written on one face or on both faces (opisthograph). When written, it was folded and sometimes sealed, the outer part still visible after folding, and could be provided with an endorsement giving the title of the deed or, if it was a letter, the names of the sender and addressee.

The shape of the sheet (higher than wide, or the opposite) and the fiber orientation (recto with horizontal or vertical fibers) are not contingent: they depend on the document genre and the period.

Contrary to a commonly held opinion, papyrus was not expensive (the $3.40 \mathrm{~m}$ long standard roll cost approximately two drachmas in the mid-first century, i.e., the price of ca. 10 liters of wheat). The ostraca were obviously cheaper but were unsuitable in most cases where papyrus or parchment was the only possible or acceptable material. Nevertheless, the writing material was only a small part of the price of books: it was the cost of copying which made books expensive in Antiquity.

SEE ALSO: Books; Papyrology.

\section{REFERENCES AND SUGGESTED READINGS}

Bagnall, R. S. (2009) Livres chrétiens antiques d'Égypte: esp. 51-73 on the price of books.

Bülow-Jacobsen, A. (2009) "Writing materials in the ancient world." In R. S. Bagnall, ed., Oxford handbook of papyrology: 3-29. Oxford. 
Johnson, W. A. (2004) Bookrolls and scribes in Oxyrhynchus. Toronto.

Lewis, N. (1974) Papyrus in Classical Antiquity. Oxford.

Lewis, N. (1989) Papyrus in Classical Antiquity. A supplement. Brussels.

Skeat, T. C. (1982) "The length of the standard papyrus roll and the cost advantage of the codex."
Zeitschrift für Papyrologie und Epigraphik 45: 169-75.

Skeat, T. C. (1995) "Was papyrus regarded as 'cheap' or 'expensive' in the ancient world?" Aegyptus 75: 75-93.

Turner, E. G. (1978) The terms recto and verso: the anatomy of the papyrus roll. Brussels. 